\title{
Integrated nutrient management - promising way to reduce carbon dioxide and methane emission in flooded rice ecosystem: $A$ review
}

\section{Ravikumar*}

Department of Agronomy, Faculty of Agriculture, Annamalai University, Annamalai Nagar-608002 (Tamil Nadu), India

\section{Ganapathy}

Department of Agronomy, Faculty of Agriculture, Annamalai University, Annamalai Nagar-608002 (Tamil Nadu), India

\section{A. Karthikeyan}

Department of Agronomy, Faculty of Agriculture, Annamalai University, Annamalai Nagar-608002 (Tamil Nadu), India

\section{P. Senthilvalavan}

Department of Soil Science and Agricultural Chemistry, Faculty of Agriculture, Annamalai University, Annamalai Nagar-608002 (Tamil Nadu), India

\section{R. Manivannan}

Department of Soil Science and Agricultural Chemistry, Faculty of Agriculture, Annamalai University, Annamalai Nagar-608002 (Tamil Nadu), India

*Corresponding author. Email: ravikumarchinnathambi@gmail.com

\section{How to Cite}

Ravikumar, C. et al. (2021). Integrated nutrient management - promising way to reduce carbon dioxide and methane emission in flooded rice ecosystem: A review. Journal of Applied and Natural Science, 13(1): 385 - 395. https://doi.org/10.31018/ jans.v13i1.2570

\begin{abstract}
Climate change is an inevitable ruling issue caused by the increasing concentration of greenhouse gases (GHGs) in the atmosphere worldwide. It will have a considerable impact on agriculture and its related fields like live stocks and fisheries. In India, the main sectors contributing to these emissions are industry, agriculture and waste, with a total emission of $334 \mathrm{MT} \mathrm{CO2} \mathrm{eq.} \mathrm{Be-}$ sides, the major sources in agriculture are enteric fermentation $(63.4 \%)$, rice cultivation $(20.9 \%)$, agricultural soils $(13.0 \%)$, manure management $(2.4 \%)$ and on-field burning is the crop residue $(2.0 \%)$. Thus, the crop productivity sector (rice cultivation, soil and field burning of crop residues) contributes $35.9 \%$ to the total emission from agriculture. Therefore, reducing GHG emissions and enhancing the $C$ sequestration in soil and biomass has become challenging. However, the total GHG's emission from all sectors of the country has decreased from $33 \%$ in 1970 to $18 \%$ in 2010 . Cutting off GHGs emission from agriculture can be achieved by sequestering $\mathrm{C}$ and reducing methane emissions $(\mathrm{CH} 4)$ and carbon dioxide $(\mathrm{CO} 2)$ through various soil and crop management strategies. Integrated nutrient management (INM) practice ensures the Soil -plant -atmospheric continuum (SPAC) in a promising way, reducing the GHGs emission by sequestering more carbon to soil than emissions. A studious prominent INM solution can be identified to develop a mitigation strategy that helps in climate change adaptation and sustains soil health through soil carbon sequestration.
\end{abstract}

Keywords: $\mathrm{CO}_{2}, \mathrm{CH}_{4}$, Carbon sequestration, Climate change, Integrated nutrition management.

\section{INTRODUCTION}

Global warming is the most predominant environmental issue across the world. Among the various sources of GHG's agriculture is considered a major contributor, primarily through methane, carbon dioxide, and nitrous oxide. In addition to that, biogenic sources contribute to over $70 \%$ of the global $\mathrm{CH} 4$ emissions and paddy fields, as major anthropogenic sources of $\mathrm{CH} 4$ emis- sions account for $5-19 \%$ of the global anthropogenic $\mathrm{CH} 4$ budget and climate change (Wang et al., 2015). According to a report of Indian Network for Climate Change Assessment, the net emission of GHG's from India was 1728 million tons (MT) of $\mathrm{CO} 2$ eq. in the year 2007. The main sectors contributing to these emissions are industry, agriculture and waste, with a total emission of 334 MT CO2 eq. The major sources in agriculture are enteric fermentation $(63.4 \%)$, rice cultivation 
(20.9\%), agricultural soils $(13.0 \%)$, manure management $(2.4 \%)$ and on-field burning is the crop residue $(2.0 \%)$.

Various agricultural activities such as land clearing, cultivation of crops, irrigation, animal husbandry, fisheries and aquaculture have a significant impact on the emission of GHGs (IPCC, 2014). Hence, it is, therefore, pertinent to develop technologies to reduce $\mathrm{CH} 4$ and $\mathrm{CO} 2$ emission from the cereal-based crop production system. Among the various strategies, manure management contributes a considerable share in sustaining soil fertility and reducing GHG's emission. Pertaining to nutrient management, the addition of nutrients throughinorganic fertilizers is inevitable for any crop grown in the conventional cropping method. However, in recent years there has been serious concern about the long term adverse effects of continuous and indiscriminate use of inorganic fertilizers on the deterioration of soil structure, soil health and environmental pollution (Singh, 2000).

The utilization of indigenous organic sources like farmyard manure (FYM), other forms of compost and green manures may serve as alternatives or supplements to chemical fertilizers and increase the productivity of the rice-based cropping system all parts of the country (Manivannan and Sriramachandrasekharan, 2016). Soil fertility management is more important for higher crop production, maintenance of fertility and sustainable crop production.

Integrated nutrient management (INM) practices involving organic and inorganic sources based on their availability and cost-effectiveness and the judicious combination of these two sources have been mutually reinforced. The efficiency of both sources results in higher productivity and soil fertility. Besides, the application of organic manures alone during anoxic condition eventually increased the GHGs emission, whereas, combined with inorganic fertilizers enhanced the soil organic carbon content rather than the emission. An in-depth understanding of the trends in GHG emissions, their regardless drivers, and the relation between the two is essential for comprehending the need for mitigation. Hence, the present review aspires to reveal the effect of INM on $\mathrm{CO} 2$ and $\mathrm{CH} 4$ fluxes and yield potential in rice-based production system. Simultaneously, the objectives of this paper are to reveal the emission of GHGs from Indian agriculture and analyze the appropriate combination of INM practice to sequester more soil carbon rather than the GHGs emission to sustain the soil health and mitigating climate change with increased yield potential of crops.

Organic manures on $\mathrm{CO}_{2}$ emission in rice production Agricultural management practices that include changing the soil environment $(\mathrm{C} / \mathrm{N}$ ratio of substances, soil temperature, and soil moisture) affect soil $\mathrm{CO} 2$ flux. These soil characteristics affect the microbial activity in the soil and its decomposition that transforms plantderived $\mathrm{C}$ into $\mathrm{CO} 2$ and soil organic matter SOM (Franzluebbers et al., 1995). Though the soil carbon mineralization and $\mathrm{CO}_{2}$ evolution have been paid great attention for their important effects on global carbon cycle and terrestrial ecosystem functioning (IPCC, 2001; Valentini et al., 2000; Jenkinson et al., 1991). The maximum $\mathrm{CO} 2$ flux recorded in organic amendment can be attributed to the combined effects of available $C$ substrate, soil temperature, moisture regimes over the non- amended treatment reported by (Smith et al., 2003), and higher microbial activity (Rochette et al., 2004. Relatively some research studies concluded that the cumulative carbon dioxide flux was higher in the treatments received cow dung (CD) application (854 $\mathrm{mg} \mathrm{kg}^{-1}$ ) followed by cow dung + rice straw (RS) $\left(828 \mathrm{mg} \mathrm{kg}^{-1}\right)$ and cow dung + lime (780 $\mathrm{mg} \mathrm{kg}^{-1}$ ) application (Naher et al., 2004). similarly, the animal manure is act as a readily-available source of $\mathrm{C}$ and its application had a positive influence on microbial activity that can increase $\mathrm{CO} 2$ emissions in annual cropping system (Rochette et al., 2004) and also, a higher value of $\mathrm{CO} 2$ flux $(706 \mathrm{~g} \mathrm{CO} 2 \mathrm{Cm}-2)$ recorded through the application of organic manure- $\mathrm{N}$

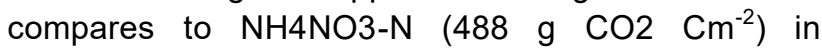
switchgrass (Lee et al., 2007). In contrast, the application of organic substances or manure at high rates in the fields caused the deposition of soil and organic substances, which reacted with soil particles to form complex compounds that were hardly decomposed into carbon dioxide (Suwannarit, 2008). Incorporating rice residues for the next season, cropping is an important practice followed by the farmers in the low land ecosystem. Rice residues were categorized as lowquality organic material since they comprise a high content of carbon (367-423 g kg $\left.{ }^{-1}\right)$, and low content of nitrogen $\left(4.7-8.5 \mathrm{~g} \mathrm{~kg}^{-1}\right)$ and lignin $\left(19-45 \mathrm{~g} \mathrm{~kg}^{-1}\right)$. Wherever it is incorporated into soils with optimal conditions, it rapidly decomposes and leads to an increase in $\mathrm{CO} 2$ evolution (Samahadthai et al., 2010; Puttas et al., 2011). Whereas the incorporation of maize straw into soil along with nitrogen and sufficient moisture levels significantly affected the rates and cumulative $\mathrm{CO} 2-\mathrm{C}$ evolution. It brought roughly a $50 \%$ increase in collective CO2-C production compared to control (Abro et al., 2011). Similarly, in research studies, the results of Koul et al. (2011) indicated that the conventional land use system recorded lesser value of SOC content due to the minimum amount of residue addition to the soil than extent type of vegetative cover on the land. The application of organic and inorganic fertilizers highly influence soil $\mathrm{CO}_{2}$ and $\mathrm{CH}_{4}$ emissions (Nyamadzawo et al., 2014).In addition to that application of organic fertilizers can enhance microbial decomposition activities and 
root respiration, leading to the increase of the $\mathrm{CO}_{2}$ emission of soil (Qiu et al., 2015; Li et al., 2019). Addition of oil cake fertilizer significantly increased soil MBC content and $\mathrm{CO}_{2}$ emissions, especially single cake fertilizer alone nourished treatments showed the highest emissions (Lin et al., 2021).

\section{Organic manures on $\mathrm{CH}_{4}$ emission in rice production}

Agriculture contributed globally over $11 \%$ of the total GHG's emission. Indian agricultural sector, including crop and animal husbandry, emitted $418 \mathrm{Mt}$ of $\mathrm{CO} 2 \mathrm{eq}$. Enteric fermentation, i.e., emission from ruminant animals, contributed the highest $(56 \%)$ amount of the emission from this sector, followed by agricultural soil $(23 \%)$ and rice fields (18\%) (Fig. 1a). Burning of crop residues in the field contributed $2 \%$ and manure management contributed $1 \%$ of the emission. Over the years, several estimates of methane emission from Indian rice fields have been made. In recent years, Indian Agricultural Research Institute, New Delhi, in collaboration with other ICAR and CSIR Institutes, has rationalized the earlier estimate of 37.5 Mt to 3.3 Mt (Fig.1b) (Pathak et al., 2014). Among the various rice ecosystems, the highest emission was from the irrigated continuously flooded rice (34\%), followed by rainfed floodprone rice and irrigated single aeration (18\%) (Bhatia et al., 2012;2013).

As far as soil concern, good-oxidized soil has a redox potential range up to $+400 \mathrm{mV}$ to $+700 \mathrm{mV}$, whereas flooded soil probably reach redox potential values lower than -300 mV (Patrick and Mahapatra, 1968). Relatively some research studies concluded that the application of organic manure hastened the fall in redox potential and enhanced $\mathrm{CH} 4$ production and emission (Yang and Chang, 1997). Especially, incorporation of rice straw in the soil significantly increased $\mathrm{CH} 4$ production by $1.2-$ 7.9 times over that of unamended soil (Majumdar et al., 1999). Adhyaet al. (1994) noticed that $\mathrm{CH}_{4}$ emissions ranged from 4 to $26 \mathrm{mg}$ of $\mathrm{C} \mathrm{m}^{-2} \mathrm{~h}^{-1}$ in a rice paddy especially a higher population of methanogenic bacteria, which is responsible for increased $\mathrm{CH} 4$ production as well as plant growth and peaked at rice maturity (Reichardt et al.,1997); concurrently intermittent irrigation reduces $\mathrm{CH}_{4}$ emission by $36 \%$ compared to a continuous flooding system. The higher amount of methane emission observed from rice fields is estimated to be $3.32 \mathrm{Tg} \mathrm{CH}_{4}$ and each year contributing about 3.4 per cent to the global methane budget due to rice cultivation. (2.49 $\mathrm{Tg} \mathrm{CH} \mathrm{CH}_{4}-\mathrm{C}$ ) (Xiang and $\mathrm{Ng}, 1996$ and Wassmann and Aulakh, 2000). With respect to hourly emission ranged from 0.65 to $1.12 \mathrm{mg}$ of $\mathrm{C} \mathrm{m}^{-2} \mathrm{~h}^{-1}$ (Mitra et al. 1999). Besides, the average emission values are approximately $21.4 \mathrm{~g}$ of $\mathrm{C} \mathrm{m}^{-2}$, depending upon plant variety and growth environment. In organic residue-amended plots in which the first peak in $\mathrm{CH} 4$ emission (4 mg CH4-C m${ }^{-2}$ day $^{-1}$ ) was observed at maximum tillering and second peak at 70 days after transplanting (7 mg CH4-C m ${ }^{-2}$ day $^{-1}$ ) (Abao et al., 2000). In addition to that, application of Sesbania, Azolla and compost recorded the $\mathrm{CH} 4$ emission of 132, 65 and $68 \mathrm{~kg} \mathrm{ha}^{-}$ ${ }^{1}$ respectively in the wet season (Adhya et al., 2000). The extremely high ebullition due to the high input of organic manure at the beginning of the crop season is evidenced in the modelled plant biomass. Thus, root transport capacity is still low, whilst overall $\mathrm{CH}_{4}$ emissions are attained its maximum (Matthews et al., 2000). Smith et al. (2003) found that the application of animal manure is effective in terms of carbon sequestering. However, one unit of methane is equal to 23 units of $\mathrm{CO}_{2}$. However, the methane emissions associated with ruminants may counteract this positive effect. With respect to global climate, methane emissions are negative, but they symbolize energy loss from the farmer point of view. In some of the research results showed that the methane flux was high in exposed soil and it ranged between 0.04 and $0.93 \mathrm{mg} \mathrm{m}^{-2} \mathrm{hr}^{-1}$ whereas, inpuddle field of rice doubled the pace of methane emission and it ranged between 0.07 to $2.06 \mathrm{mg} \mathrm{m}^{-2} \mathrm{hr}^{-1}$ in plots nourished without organic amendments (Khosa et al., 2010). At the same time, the plots supplied through cow manure @ $12.5 \mathrm{t} \mathrm{ha}^{-1}$ emitted the maximum amount of methane (4.39 $\mathrm{mg} \mathrm{m}^{-2}$ day $\left.^{-1}\right)$ followed by the decreased rate of manure 9.38 and $3.13 \mathrm{t}^{-}$ 1attained 3.08 and $1.49 \mathrm{mg} \mathrm{m}^{-2}$ day $^{-1}$ of $\mathrm{CH} 4$ respectively in rice (Sampanpanish, 2012). Among the various organic amended plots viz., humified straw, farmyard manure, green manure and rice straw, humified rice straw plots recorded low-level emission of $\mathrm{CH} 4$ than other amended materials (Khosa et al., 2012). C release initiation differed from the addition of organic amendments to the soil probably two weeks after application, which purely depends on soil temperature, moisture regimes, and methanogenic bacteria availability. Nungkat et al. (2014) disclosed that methane emission due to the application of $10 \mathrm{t}$ organic manure and $2 \mathrm{t}$ Azolla ha ${ }^{-1}$ on paddy field ranged from 509.82 to $791.34 \mathrm{~kg} \mathrm{CH} 4 \mathrm{ha}^{-1}$. Yuan et al. (2014) opined that decomposing rice straw is performing as a substrate of $\mathrm{CH} 4$ production and kindles $\mathrm{CH} 4$ production from soil organic matter and rice root organic carbon. Organic and inorganic ways of fertilization highly influence the soil $\mathrm{CO} 2$ and $\mathrm{CH} 4$ emissions (Khan et al., 2017). Besides, the addition of straw and green manure can enhance soil methane production potentials and the abundances of methanogens (Zhou et al., 2020). However, Hoang et al. (2019) found that incorporation burned straw into the field could reduce seasonal cumulative $\mathrm{CH} 4$ emission. Besides, a positive correlation noticed between DOC and soil CO2 flux. Apparently, DOC provided energy to methanogens to promote $\mathrm{CH} 4$ production (Zhou et al., 2020). 

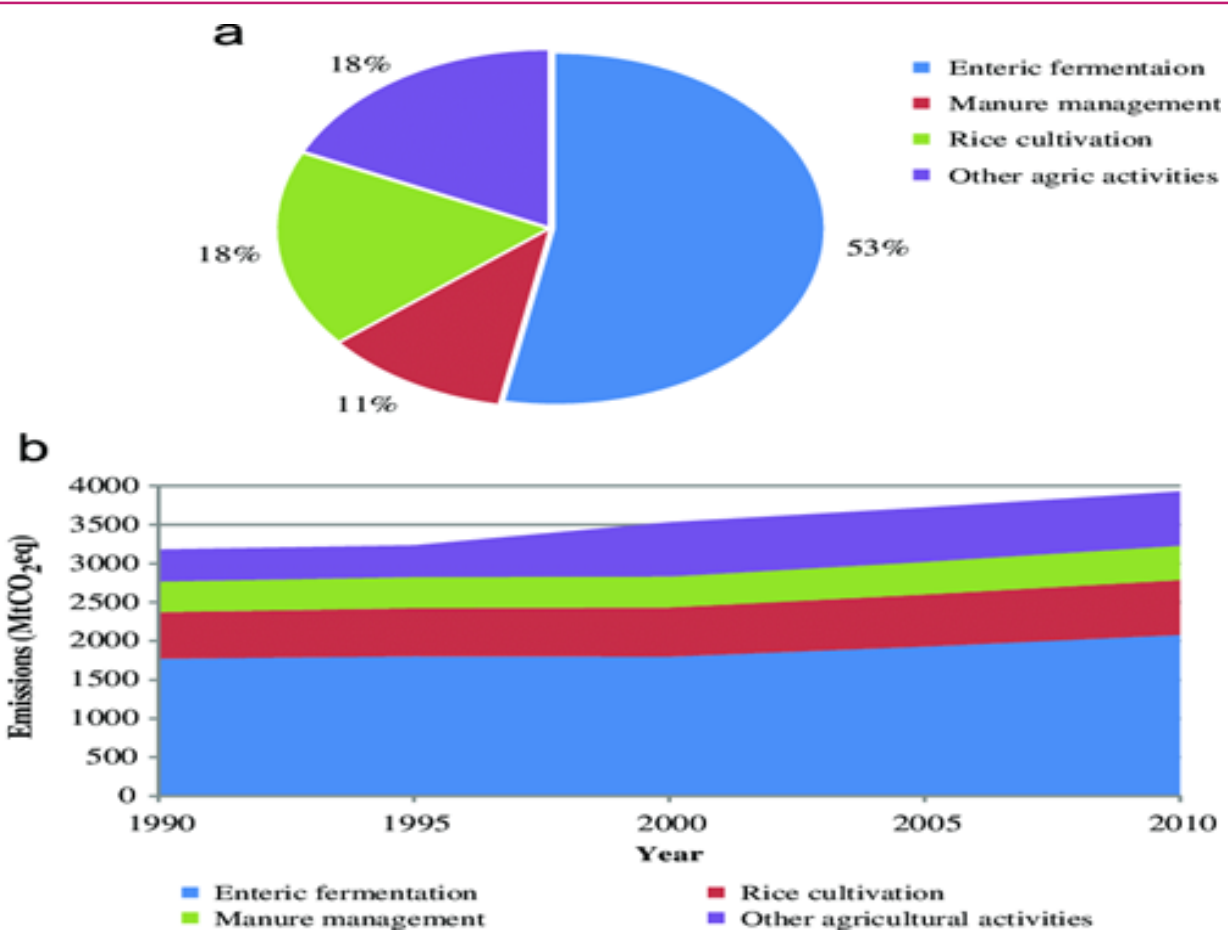

Fig.1 a. Methane emissions from Agriculture; b-Methane emission trend in the Agriculture. Source; Pathak et al., (2010.)

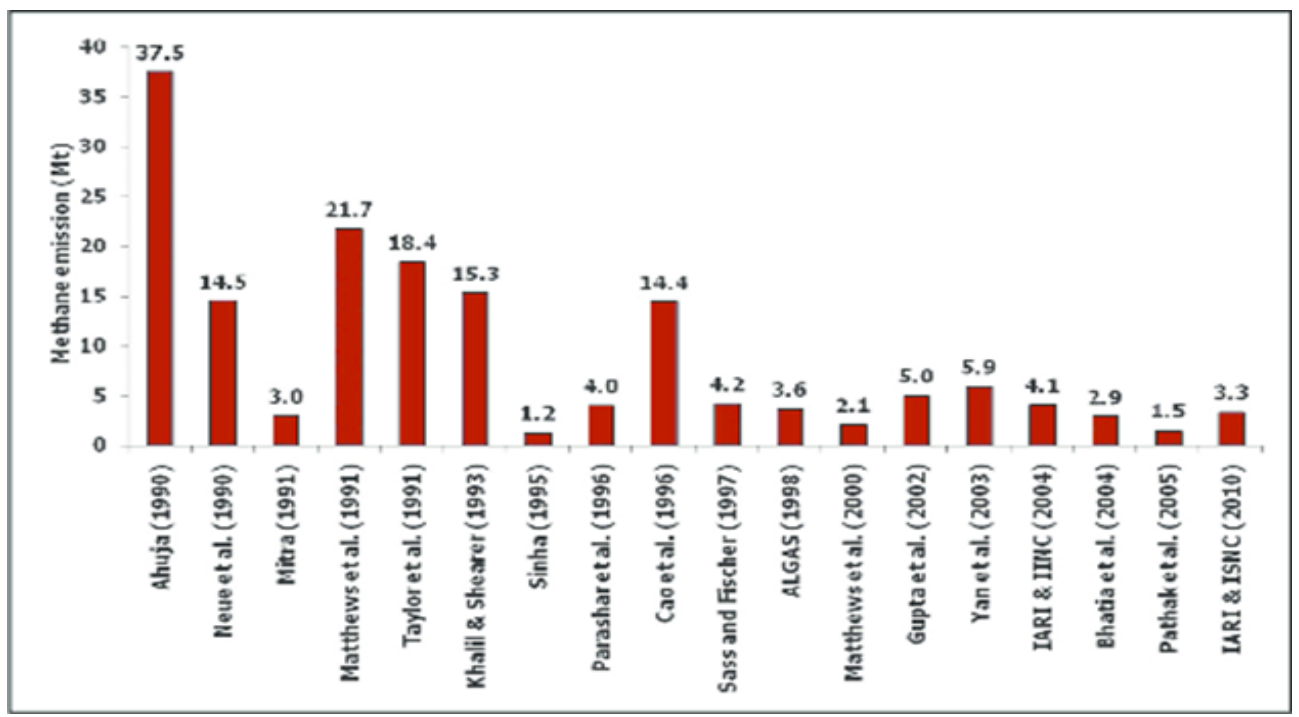

Fig.1 b. Estimates of methane emission from Indian rice fields over the years. IARI 1994, 2000, 2007 and 2010 are the values estimated by Indian Agricultural Research Institute, New Delhi for the respective years. Source: Pathak et al. (2014).

\section{Organic manures on carbon dynamics in rice production}

The continuous application of organic manures and especially FYM over a period of time increased the organic carbon content of soil (Kenchaiah, 1997). The addition of organic material in the form of municipal solid waste sewage sludge significantly increased the values of biomass carbon, basal respiration biomass $\mathrm{C} /$ total organic $\mathrm{C}$ ratio and metabolic quotient $\left(\mathrm{q} \mathrm{CO}_{2}\right)$, indicating the activation of soil microorganism (Pascal and Renin, 1997).With respect of C sequestration in paddy soils was characterized by the increase of SOC in physically protected coarse aggregates in the size of sand particles (Yuan et al., 2004). Concurrently, the application of organic fertilizers paired with the different composts has more potential of enhancing the SOC pool as compared to that of inorganic fertilizer (Held et al., 2005). The higher SOC sequestration rate was recorded in FYM addition compared to inorganic (NPK) alone plots in rice-wheat and maize-wheat cropping system (Kukal et al., 2009). With regards to various organic amendments, ahigher amount of SOC noticed under poultry litter and cattle manure application in ricewheat-legume rotation compared to farmer's practice of 
no manure and fertilizer application in rice-wheat-fallow system (Hossain, 2009). In soil profile, the processes were taken in to account include changes in the microbial biomass of $\mathrm{C}$ and $\mathrm{N}$, soil enzyme activity, microbial community composition, organic matter decomposition and functional groups of bacteria jointly responsile for trace gas emission in terrestrial and wetland ecosystems (Kundu et al., 2013). Pradhan et al. (2015) noticed that soil organic carbon stock rate was higher in daincha + FYM + Vermicompost (46.29 $\mathrm{t} \mathrm{ha}^{-1}$ ) and increased sequestration rate. Kraus et al. (2016) implied that crop residue incorporation rate of 2.8-3.4 $\mathrm{t} \mathrm{C}$ $\mathrm{ha}^{-1} \mathrm{yr}^{-1}$ in rice field after harvest is needed to accomplish stable SOC stocks in mixed upland crop-paddy rice systems. Organic materials addition not only maintains the soil fertility but also improves soil structure and soil porosity in heavy soils (Kallenbach et al., 2010; Wu et al., 2019). However, the organic way of fertilization changes the community structure of microbes and affects the decomposition of organic matter (Bao et al., 2016; Wei et al., 2019). Adding rice straw and green manure to soil are important measures to improve the organic matter content of soil (Wu et al., 2019; Yu et al., 2020). Apparently, some of the research studies have shown that soil respiration was positively correlated with soil DOC and soil microbial biomass carbon (MBC) (Ge et al., 2020).

\section{Inorganic Fertilizers on $\mathrm{CO}_{2}$ emission in rice production}

The process of carbon mineralization and $\mathrm{CO}_{2}$ evolution in soil has been paid huge attention for its vital effects on global carbon cycle and terrestrial ecosystem functioning (IPCC, 2001; Valentini et al., 2000; Jenkinson et al., 1991). Many research workers reported that applying 25 or 50 per cent $\mathrm{N}$ fertilizer with Glyricidia significantly enhanced the $\mathrm{CO} 2$ evolution, indicating a higher respiration rate than the fertilized soil in the upper 0 to $15 \mathrm{~cm}$ depth (Maheswara Prasad and Prabhu Prasadini, 2014). The highest $\mathrm{CO}_{2}-\mathrm{C}$ release was observed on $14^{\text {th }}$ day in treatments (fmv) mineral fertilizer application + (fov) manure application (3.94 mg C $100 \mathrm{~g}^{-1}$ soil), with respiration the first day (9.44 $\mathrm{mg} \mathrm{C}$ $100 \mathrm{~g}^{-1}$ soil) compared to other treatments (Segdaet al., 2014). Whereas 75 per cent $\mathrm{N}+$ Cynaobacteria significantly increased $\mathrm{CO}_{2}$ evolution (185.36 mg CO $\mathrm{mg}^{-1}$ dry $\left.{ }^{1}\right)$ compared to control (Abbas et al., 2015). Wang et al. (2015) reported that maximum enhancement of rice yield was observed at $600-699 \mathrm{ppm} \mathrm{CO}_{2}$ than lower or higher elevated $\mathrm{CO}_{2}$ levels. Similarly, with respect to the crop stage, the higher rate of CO2 emission (539.6 $\mathrm{mg} \mathrm{m}^{-2}$ day $^{-1}$ ) was recorded with chemical fertilizer treatments during the panicle initiation stage compared to other rice growth stages (Redeker et al., 2000). Besides that, the application of $\mathrm{N}$ fertilizer and urea significantly influence most biological processes in the soil
(Yan et al., 2007), and their application most probably enhanced mineralization, carbon sequestration, and nutrient cycling (Bastidaet al., 2006). Concurrently some of the research evidence proved that application of NPK + FYM (2.47 Mg ha ${ }^{-1}$ ) and NPK + PS (1.41 Mg ha-1) sequestered higher carbon in Kharif season (Ghosh et al., 2012). The emission of $\mathrm{CO} 2$ and $\mathrm{CH} 4$ gases recorded higher value with the application of inorganic fertilizers compare with organic fertilizers (Sampanpanishet al., 2012) and that to eventually increased with the addition of urea, with a maximum at the rate of $250 \mathrm{~kg} \mathrm{~N} \mathrm{ha}^{-1}$ (Tanget al.,1999). Furthermore, the addition of chemical fertilizer affects the greenhouse gas (GHG) fluxes from soil (Chen et al., 2017; Liu et al., 2018). Many studies have shown that the application of chemical fertilizers increases soil $\mathrm{CO}_{2}$ emissions (Zhang et al., 2019). Chemical fertilizers with different compounds with deviations in $\mathrm{C} / \mathrm{N}$ ratio may affect soil physicochemical properties and soil CO2 emission (Gwon et al., 2019). tang2019). Decreasing conventional rate of untreated urea (CRU) application and the incorporation of organic fertilizer into $\mathrm{CRU}$ have the potential for mitigating of $\mathrm{CO} 2$ emission and positive effect on the soil microbial functional diversity to improve nitrogen use efficiency of rapeseed (Zhang et al., 2020).

\section{Inorganic fertilizers on $\mathrm{CH}_{4}$ emission in rice production}

The methane emission from inorganic fertilizer (Urea) treated plots recorded $<30 \mathrm{~g} \mathrm{ha}^{-1}$ day $^{-1}, 12.04 \mathrm{~kg} \mathrm{ha}$ ${ }^{1}$ day $^{-1}$ and $4.6 \mathrm{~kg} \mathrm{ha}^{-1}$ day $^{-1}$ during seedling, Panicle Initiation and flowering stages, respectively in rice (Lindau et al., 1993). However, the increasing atmospheric $\mathrm{CH} 4$ emissions directly correlate with the per cent of soil sand content ranging from 18.8 to $32.5 \%$ and the seasonal methane emissions ranged from 15.1 to 36.3 $\mathrm{gm}^{-2}$ in rice (Sass et al., 1994). Schimel (2000) found that the application of $\mathrm{N}$ fertilizer could increase crop canopy and provide rich organic matter for methanogens, effectively utilizing roots and root exudates as a carbon source for their nourishment.

Methane emission from the $\mathrm{NH} 4$ and NO3-N applied plots (mean of $256 \mathrm{mg} \mathrm{CH} 4 \mathrm{~m}^{-2} \mathrm{~d}^{-1}$ ) were not significantly differ from that of control (mean value of $225 \mathrm{mg} \mathrm{CH} 4$ $\mathrm{m}^{-2} \mathrm{~d}^{-1}$ ) (Dise and Verry, 2001). Nitrogen fertilizers enhanced crop growth and provided more $C$ substrates through organic root exudates and sloughed-off cells to methanogens, leading to increased $\mathrm{CH} 4$ production (Inubushi et al., 2003). Besides that, inorganic N fertilizer in paddy fields enhanced the growth and activity of methanogens, leading to increasing $\mathrm{CH} 4$ emissions (Bodelier and Lannbroek, 2004). Exclusively the application of urea fertilizer and its rate decides the $\mathrm{CH} 4$ emission, which is likely a result of an increase in soil $\mathrm{pH}$ by urea hydrolysis and a decrease in redox potential probably leads to enhance methanogenic activities 
in the paddy field (Dubey, 2005). However, the $\mathrm{CH} 4$ emission was hiked with an increased $\mathrm{N}$ fertiliser application rate, but a higher rate of $\mathrm{N}$ could eventually decrease the $\mathrm{CH} 4$ emission in rice (Linquist et al., 2012).

Sampanpanish (2012) opined that the $\mathrm{CH} 4$ emission recorded a higher value $\left(3.03 \mathrm{mg} \mathrm{m}^{-2} \mathrm{day}^{-1}\right)$ in treatments with chemical fertilizer followed by organic fertilizer pellets $\left(2.88 \mathrm{mg} \mathrm{m}^{-2} \mathrm{day}^{-1}\right)$, organic fertilizer (1.68 $\mathrm{mg} \mathrm{m}^{-2} \mathrm{day}^{-1}$ ) in rice. Kim et al. (2016) revealed that the $\mathrm{CH} 4$ oxidation potential significantly increased with increasing $\mathrm{N}$ fertilization levels $\left(115-137 \mathrm{~kg} \mathrm{~N}^{-1}\right)$, and is highly related to the accumulation of total biomass, straw and root biomass productivities in rice. In controversy, the average $\mathrm{CH} 4$ emissions for non-fertilized and fertilized parts were 15.5 and $11.4 \mathrm{mg} \mathrm{CH}^{-1} \mathrm{~m}^{-2} \mathrm{~h}^{-1}$ in the first crop and 16.8 and $11.8 \mathrm{mg} \mathrm{CH}^{4} \mathrm{~m}^{-2} \mathrm{~h}^{-1}$ in the second crop, respectively (Ooet al., 2015). Whereas, a higher rate of $\mathrm{N}$ fertilizers increase the soil salinization and decrease the organic matter content which in turn leads to decrease in $\mathrm{CH} 4$ emission in rice (Wang et al., 2016). Various proportions of fertilizers with dissimilarities in $\mathrm{C} / \mathrm{N}$ ratio may affect soil physicochemical properties, and soil $\mathrm{CO} 2$ and $\mathrm{CH} 4$ emission (Zhou et al., 2017). Kong et al. (2019) observed that the application of $\mathrm{N}$ fertilizer improved the soil carbon (C) substrate and benefited the methanogens proliferation to improve methanogenic activities and thus promote $\mathrm{CH} 4$ emissions. Fertilizers with low $\mathrm{C} / \mathrm{N}$ ratio can substantially increase the decomposition of residues and contribute to GHG emissions (Zhou et al., 2019). Similarly, some research studies have shown that soil respiration was positively correlated with soil $\mathrm{DOC}$ and soil microbial biomass carbon (MBC) (Wu et al., 2020) and application of nitrogenous fertilizers was not influenced $\mathrm{CH} 4$ emission (Lin et al., 2021).

\section{Inorganic fetilizers on carbon dynamics in rice production}

The application of chemical fertilizers is necessary to enhance crop yields and sustain soil fertility (Yadav et al., 2000). Singh and Namdeo (2004) divulged that the application of increased recommended dosage of fertilizers enhanced the nutrient absorption in rice. Kamble et al. (2008) documented that the application of 125 per cent of RDF significantly increased the nutrient uptake when compared with lower levels in rice. Scherer (2009) opined that sulphur occurs in organic and inorganic forms and is cycled between these forms through various processes such as mobilization, mineralization, immobilization, oxidation and reduction. Functionally, $S$ significantly influences yield and quality of crops, improves odour and flavours, and imparts resistance to cold, and hence it is generally considered a "quality nutrient" (Usharaniet al., 2009). The organic source of nutrients has the added advantage of steady and slow release of nutrients for maintaining an ideal $\mathrm{C}$ : $\mathrm{N}$ ratio, improvement in the water holding capacity and soil microbial biomass, without impairing any adverse residual effects (Yadav et al., 2010). Badar and Qureshi (2014) revealed that composting of organic wastes with the support of microbial inoculation enhanced the total carbohydrates and crude protein contents which might work as a good source of carbon and hydrogen and it may facilitate to restore or increase the fertility of degraded soil. In addition to the single application of chemical or organic fertilizer, the combined application of both is the main measure of agricultural fertilization (Zhou et al., 2019; Qaswar et al., 2020). Soil nitrate nitrogen (NO3 $-\mathrm{N}$ ) and $\mathrm{NH} 4-\mathrm{N}$ provide essential nutrients for microbes and indirectly affect soil microbes and gas emissions. The process of nitrification and denitrification was affected by the soil $\mathrm{pH}$ and affected the activity of soil microbes ( Li et al., 2020).

\section{INM on $\mathrm{CO}_{2}$ emission in rice production}

The application of cow dung ( $\left.3 \mathrm{t} \mathrm{ha}^{-1}\right)$ combines with NPK (15:15:15) recorded eventually increased value of organic carbon from 1.33 to $3.21 \%$ and also enhanced soil organic matter, exchangeable ions, effective cation exchange capacity and $\mathrm{pH}$ in comparison to untreated plot (Onwudike, 2010). Similarly, Pathak et al. (2011) pointed that the application of inorganic fertilizers with organic manure (NPK + FYM) recorded a higher SOC concentration than inorganic fertilizers (NPK) alone in all the longtime experiments. Moharana et al. (2012) advocated that the application of FYM either alone or in combination with inorganic fertilizers registered a considerable amount of total SOC accumulated in 10-15 $\mathrm{cm}$ soil layer than unfertilized control plots. Concomitantly, the application of NPK either through inorganic fertilizers or through inorganic fertilizer judicially combined with organic manures such as farmyard manure (FYM) or crop residue or green manure improved SOC, particulate organic carbon (POC), microbial biomass carbon (MBC) concentration and as well as their sequestration rate (Nayak et al., 2012). Lal (2014) suggested that the INM improves soil fertility and for healthy crop growth and eventually biochemical transformation of biomass $C$ into SOM or humus.

Maheswara Prasad and Prabhu Prasadini (2014) suggested that the application of 25 or 50 per cent $\mathrm{N}$ fertilizer with Glyricidia sp. significantly enhanced the $\mathrm{CO} 2$ fruition indicating higher respiration rate than the unfertilized soil in the upper 0 to $15 \mathrm{~cm}$ depth. Segadaet al. (2014) disclosed that the higher level CO2-C noticed on the $14^{\text {th }}$ day in treatments which received mineral fertilizer combined with organic manure $(3.94 \mathrm{mg} \mathrm{C} 100 \mathrm{~g}-1$ soil), with respiration of $9.33 \mathrm{~g}$ of $\mathrm{C} 100 \mathrm{~g}-1$ of soil in the first day. Abbas et al. (2015) recorded that $75 \% \mathrm{~N}+$ Cyanobacteria application significantly enhanced the CO2 evolution (185.36 mg CO2 g g $\mathrm{dry}^{-1}$ ) compared to control in rice. 
Combined use of chemical fertilizers, $2.0 \mathrm{t} C$ ha- 1 fresh rice straw and continuous flooding system performed better results to reduce $\mathrm{CO} 2-\mathrm{C}$ gas emission, increased organic carbon and rice production with maintaining optimum soil $\mathrm{pH}$ level with sustainable rice production (Hossain, 2018).

\section{INM on $\mathrm{CH}_{4}$ emission in rice production}

The maximum $\mathrm{CH} 4$ emission rate $\left(4.86 \mathrm{mg} \mathrm{m}^{-1} \mathrm{ha}^{-1}\right)$ was observed with FYM + urea treatment than, biogas slurry + urea treated plots (Debnath et al., 1996). The combined application of NPK and Azolla compost had a significant influence on the accumulation of soil carbon $\left(16.93 \mathrm{~g} \mathrm{~kg}^{-1}\right)$ and capacity of soil carbon storage (28.1 $\mathrm{Mg} \mathrm{C} \mathrm{ha}{ }^{-1}$ ) with high carbon efficiency ratio (16.9) and also its application significantly enhanced $\mathrm{CH} 4$ emission $(15.66 \%)$ carbon storage of soil and improved the ability of grain yield $\left(6.55 \mathrm{Mg} \mathrm{ha}^{-1}\right)$ over other treatments (Adhyaet al., 2000). Apparently, the application of organic C through FYM increased the GHG emissions (Pathak et al., 2002). Application of FYM @ $12.5 \mathrm{t}$ ha $^{-1}$ integrated with 100\% RDF + Azospirillum and Phosphobacteria @ $2 \mathrm{~kg} \mathrm{ha}^{-1}$ recorded a lower value of 4.4 and 2.06, 7.2 and 1.94 and 2.7 and $1.59 \mathrm{mg} \mathrm{m}^{-2} \mathrm{~h}^{-1}$ $\mathrm{CH}_{4}$ emission during both the day and night time at 40 , 80 DAS and at harvest respectively over other organic manure combinations during the Thaladiseason of the rice crop (Ravikumar and Ganapathy, 2018). The integrated application of urea and oilseed rape cake fertilizer reduced the emission of $\mathrm{CO} 2$, whereas enhanced the emissions of $\mathrm{CH} 4$ (Lin et al., 2021).

\section{INM on carbon dynamics in rice production}

Application of inorganic fertilizers (NPK $100 \%$ ) integrates with organic manure (FYM $10 \mathrm{t} \mathrm{ha}^{-1}$ ) showed a positive influence on all soil properties, especially soil organic carbon Pothare et al., 2007). Concurrently, the addition of inorganic fertilizers with various organic manures in rice-wheat system enhanced the aggregation of the soil which paves way for higher storage of SOC content (Singh et al., 2009). A Higher soil quality index (1.61) was noticed with the application of $25 \mathrm{~kg}$ nitrogen ( $\mathrm{N}$; compost) as well as with the application of 15 $\mathrm{kg} \mathrm{N}$ (compost) $+10 \mathrm{~kg} \mathrm{~N} \mathrm{ha}^{-1}$ (green leaf) (Sharma et al., 2015). Akhilesh and Nandan (2016) noticed that a higher soil organic carbon stock $\left(43.77 \mathrm{t} \mathrm{ha}^{-1}\right)$ and an enhanced rate of sequestration (2.69 $\left.\mathrm{t} \mathrm{ha}^{-1} \mathrm{yr}^{-1}\right)$ was recorded in the treatment Dhanicha+ FYM + Vermicompost application. Cattle manure with high $\mathrm{C} / \mathrm{N}$ ratio combined with chemical fertilizers significantly increased the microbial biomass $\mathrm{C}$, soil organic $\mathrm{C}$, soil total $\mathrm{N}$, soil mineral $\mathrm{N}$ and soil $\mathrm{CO} 2-\mathrm{C}$ flux in black cumin crop (Nigella sativa L.) (Salehi et al., 2017). Similarly, Kamp et al. (2017) documented that in the long term, cultivation requires balanced fertilization through NPK integrates with FYM, eventually increased the SOC content and SOC stocks and the carbon sequestration potential (1.77 Mg ha-1). The quantities of SOC at the 0 $-400 \mathrm{~kg}$ of soil $\mathrm{m}-2$ interval decreased under $\mathrm{ZT}$ without residue (T1), PRB without residue (T4) and Conventional tillage (T7) treatments evaluated. Stocks of SOC in the top $400 \mathrm{~kg}$ of soil m-2 decreased from 7.46 to $7.15 \mathrm{~kg}$ of $\mathrm{C} \mathrm{m}-2$ represented a change of $-0.31 \pm 0.03$ $\mathrm{kg}$ of $\mathrm{C} \mathrm{m}-2$ in $\mathrm{T} 1,8.81$ to $8.75 \mathrm{~kg}$ of $\mathrm{C} \mathrm{m}-2$ represented a change of $-0.06 \pm 0.05 \mathrm{~kg}$ of $\mathrm{C} \mathrm{m}-2$ in T4 and 5.92 to 5.22 of $\mathrm{C} \mathrm{m}-2$ represented a change of $-0.70 \pm 0.09 \mathrm{~kg}$ of C m-2 in T7 between 2000 and 2016 (Naresh et al., 2017). A higher soil organic carbon with a value of 7.8 and $8.6 \mathrm{~g} \mathrm{~kg}^{-1}$ were recorded with the application of FYM @ $12.5 \mathrm{t} \mathrm{ha}^{-1}$ integrated with 100\% RDF + Azospirillum and Phosphobacteria @ 2 kg ha ${ }^{-1}$ over other organic manure combinations in the successive years of rice crop (Ravikumar and Ganapathy, 2018). The application of organic manures along with chemical fertilizer and continuous flooded condition paves the way for the highest organic carbon accumulation which is a key factor for improvement of soil quality and minimized environmental pollution (Hossain, 2018).

\section{Conclusion}

Agricultural practices are the major sources of GHGs emission. Hence, it is also mitigate GHGs emissions through reduction in $\mathrm{CO}_{2}$ and $\mathrm{CH}_{4}$ emissions, as well as carbon sequestration. A concrete understanding of how much carbon can be sequestered by different practices is more important inmaking solid decisions about the most appropriate mitigation strategies. Among the various strategies, manure management contributes a considerable share in sustaining soil fertility and reducing GHG emissions. The addition of nutrients throughinorganic fertilizers is inevitable for any crop grown in the conventional cropping method. However, there has been serious concern about long-term adverse effects of incessant and blanket use of inorganic fertilizers on soil structure deterioration, soil health on and above environmental pollution in recent years. The continuous use of imbalanced inorganic fertilizers, is subject to various losses and might be converted into different gas emissions, leading to global warming. Simultaneously, the addition of organic amendments may be very useful in tropical regions, especially in southern parts of India. However, the application of organic manures alone during anoxic condition ultimately enhanced the GHGs emission, whereas, combined with inorganic fertilizers improved the soil organic carbon content rather than the $\mathrm{CO}_{2}$ and $\mathrm{CH}_{4}$ emission. The emission of GHGs are quite inevitable from the total global perspective. But the measuring ways of GHG emission found are complex and uncertain. Therefore, there is a need for user-friendly, costeffective methods for GHGs quantification that work 
across regions and systems. Though there are many significant opportunities for GHGs mitigation in agriculture, numerous obstructions need to be conquered. It would also require increased Research and Development efforts on mitigation and adaptation, development activities, manure and land-use management changes.

\section{Conflict of interest}

The authors declare that they have no conflict of interest.

\section{REFERENCES}

1. Abao, Jr. E. B., Bronson, K.F.,Wassmann, R. and Singh, U.(2000). Simultaneous records of methane and nitrous oxide emissions in rice-based cropping systems under rainfed conditions. Nut. Cycl. Agroecosys. 58, 131-39.

2. Abbas, H. H., Ali, M. E., Ghazal, F. M. and El-Gaml. N. M. (2015). Impact of Cynobacteria inoculation on rice (Oryza sativa) yield cultivated in saline soil. J. Am. Sci., 11 (2),13-19.

3. Abro, S.A., Tian, X.H., You, D.H. and Wang, X. D. (2011) Emission of carbon dioxide influenced by nitrogen and water levels from soil incubated straw. PI. Soil Environ. 57(6), 295-300.

4. Adhya, T. K., Bharati, K., Mohanty, S. R., Ramakrishnan, B., Rao, V. R., Sethunathan, N. and Wassmann, R. (2000). Methane emission from rice fields at Cuttack, India. Nutr. Cycl. Agroecosyst., 58, 95-105.

5. Adhya, T.K., Rath, A.K., Gupta, P.K., Rao, V.R., Das, A.N Parida, K.M., Parasha, D. C. and Sethunathan, D. (1994). Methane emission from flooded rice fields under irrigated condition, Biol. Fertil. Soil, 18, 245-248.

6. Badar, R. and Qureshi, S.A. (2014). Composted Rice Husk Improves the Growth and Biochemical Parameters of Sunflower Plants. Journal of Botany, 2014, 6. https:// doi.org/10.1155/2014/427648

7. Bao, Q, Huang, Y, Wang, F, Nie, S, Nicol, GW, Yao, H, Ding, L. (2016). Effect of nitrogen fertilizer and/or rice straw amendment on methanogenic archaeal communities and methane production from a rice paddy soil. Applied Microbiology and Biotechnology, 100(13), 59895998. DOI: http://dx.doi.org/10. 1007/s00253-016-7377-z.

8. Bastida, F., Moreno, J.L., Hernandez, T. and Garcıa (2006). Microbiological degradation index of soils in a semiarid climate. Soil Biol. Biochem., 38, 3463-3473.

9. Bhatia A, Aggarwal P.K, Jain, N. and Pathak, H. (2012) Greenhousegas emission from rice and wheat-growing areas in India: Spatial analysis and upscaling. Greenhouse Gas Sci. Technol., 2,115-125

10. Bhatia, A., Jain, N. and Pathak, H. (2013) Methane and nitrous oxide emissions from Indian rice paddies, agricultural soils and crop residue burning Greenhouse Gas. Sci. Technol., 3, 196- 211.

11. Bodelier, P.L.E. and Laanbroek, H.J. (2004). Nitrogen as a regulatory factor of methane oxidation in soils and sediments. FEMS Microbiol. Ecol., 47: 265-277.

12. Chen, D, Li, Y,Wang, C, Fu, X, Liu, X, Shen, J,Wang, Y, Xiao, R, Liu, DL,Wu, J. (2017). Measurement and modeling of nitrous and nitric oxide emissions from a tea field in subtropical central China. Nutrient Cycling in Agroecosystems107(2), 157-173. DOI: http://dx.doi.org/10.1007/s107
05-017-9826-1

13. Debnath, G., Jain, M.C., Kumar, S., Sarkar, K. and Sinha. S.K. (1996). Methane emission from rice fields amended with biogas slurry and farm yard manure. Climate Ch.,33: 97-109.

14. Dise, N.B., and Verry, E.S. (2001). Suppression of peat land methane emission by cumulative sulfate deposition in simulated acid rain. Bio-geochemistry, 53: 143-160.

15. Dubey, S.K. (2005). Microbial ecology of methane emission in rice agroecosystem: A review. Appl. Ecol. Environ. Res., 3: 1-27.

16. Franzluebbers, A.J. (2010) Achieving soil organic carbon sequestration with conservation agricultural systems in the southeastern United States. Soil Sci. Soc. Am. J., 74: 347357.

17. Ge, X, Cao, Y, Zhou, B, Xiao, W, Tian, X, Li, MH. (2020). Combined application of biochar and $\mathrm{N}$ increased temperature sensitivity of soil respiration but still decreased the soil $\mathrm{CO} 2$ emissions in moso bamboo plantations. Science of the Total Environment 730: 139003. DOI: http:// dx.doi.org/10.1016/j.scitotenv. 2020.139003.

18. Ghosh, S., Wilson, B., Ghoshal, S., Senapati, N. and Mandal, B. (2012). Organic amendments influence soil quality and carbon sequestration in the Indo-Gangetic plains of India. Agric, Ecosystems and Environ., 156,134-141.

19. Gwon, HS, Khan, MI,Yoon, YE, Lee, YB, Kim, PJ, Hwang, HY. (2019). Unexpected higher decomposition of soil organic matter during cold fallow season in temperate rice paddy. Soil \& Tillage Research,192, 250-257. DOI: http:// dx.doi.org/10.1016/j.still.2018.11.009.

20. Held, I.M., Delworth, T.L., Lu, J.,Findell, K.L. and Knutson, T.R. (2005). Simulation of Sahel drought in the 20th and 21st centuries. Proc. Natl. Acad. Sci., 102:17891-17896.

21. Hoang, TTH, Do, DT, Tran, TTG, Ho, TD, Rehman, HU.2019. Incorporation of rice straw mitigates $\mathrm{CH} 4$ and $\mathrm{N} 2 \mathrm{O}$ emissions in water saving paddy fields of Central Vietnam. Archives of Agronomy and Soil Science, 65(1), 113-124. DOI: http://dx.doi.org/10.1080/ 03650340.201 8.1487553.

22. Hossain, M. (2009). Nutrient and residue management for improving productivity and $\mathrm{N}$ use efficiency of rice-wheatmungbean systems in Bangladesh. In: TheProceedings of the International Plant Nutrition Colloquium XVI. Uinversity of California, Davis, CA, USA.

23. Hossain, M. B. (2018). Effects of fresh rice straw and water levels on CO2-C gas emission, soil organic carbon content and rice production. J. Bio.Sci., 7(1): 45-53.

24. Inubushi, K., Cheng, W.G. Aonuma, S., Hoque, M.M., Kobayashi, K., Miura, S., Kim, H.Y. and Okada, M. (2003). Effects of free-air $\mathrm{CO}_{2}$ enrichment (FACE) on $\mathrm{CH}_{4}$ emission from a rice paddy field. Global Change Biol., 9, 14581464.

25. IPCC (2001): Climate change 2001. The Scientific Basis. IPCC Third Assessment Report, IPCC Summary for Policy Makers. http://www.ipcc.ch/pub/guide/htm.

26. IPCC (2014) Climate Change: Mitigation of climate change Contribution of Working Group III to the Fifth assessment report of the intergovernmental panel on climate change (Edenhofer, O., R. Pichs-Madruga, Y. Sokona, E. Farahani, S. Kadner, K.Seyboth, A. Adler, I. Baum, S. Brunner, P. Eickemeier, B. Kriemann, J. Savolainen, S. Schlömer, C. von Stechow, T. ZwickelandJ.C. Minx,eds.). 
Ravikumar, C. et al. / J. Appl. \& Nat. Sci. 13(1): 385 - 395 (2021)

Cambridge University Press, Cambridge, United Kingdom and New York, NY, USA

27. Jenkinson, D.S. (1991). The turn over of organic carbon and nitrogen in soil. Philosophical Transaction. Royal Society of London, 239, 361-368.

28. Kallenbach, CM, Rolston, DE, Horwath, WR. (2010). Cover cropping affects soil $\mathrm{N}_{2} \mathrm{O}$ and $\mathrm{CO}_{2}$ emissions differently depending on type of irrigation. Agriculture Ecosystems \& Environment, 137(3-4), 251-260. DOI: http://dx.doi.or g/10.1016/j.agee.2010.02.010.

29. Kamble Ramani, Sawant, A.C. Chavan, P.G. and Pawar, P.P. (2008). Effect of integrated nutrient management on yield and $\mathrm{N}, \mathrm{P}$ and $\mathrm{K}$ uptake by hybrid rice (RTNRH- 6). Int. J. Agric. Sci., 4(2),710-711.

30. Kamp, P., Purohit, D., Mandal, M. and Rout, K.K. (2017). Nutrient management for carbon sequestration and sustainable crop production under tropical rice- rice agro ecosystem. Academy of Management, 5,117-129

31. Kenchaiah, A. (1997). Organic farming in rice, Ph.D Thesis, Tamil Nadu. Agric. Univ. Coimbatore, Tamilnadu, India.

32. Khan, A, Tan, DKY, Munsif, F, Afridi, MZ, Shah, F,Wei, F, Fahad, S, Zhou, R. (2017). Nitrogen nutrition in cotton and control strategies for greenhouse gas emissions: A review. Environmental Science and Pollution Research, 24 (30), 23471-23487. DOI: http:// dx.doi.org/10.1007/s1135 6-017-0131-y.

33. Khosa, M.K., Sidhu, B.S. and Benbi, D.K. (2010). Effect of organic materials and rice cultivars on methane emission from rice field. J. Environ. Biol., 31, 281-285.

34. Khosa, M.K., Sidhu, B.S. and Benbi, D.K. (2012). Effect of organic materials and rice cultivars on methane emission from rice field. J. Environ. Biol., 31: 281-285.

35. Kim. Gil Won, Hyo Suk Gwon, Seung TakJeong, Hyun Young Hwang and PilJoo Kim. (2016). Different responses of nitrogen fertilization on methane emission in rice plant included and excluded soils during cropping season. Agriculture Ecosystems and Environment, 230,162-168.

36. Koul, D.N., Shukla, G., Panwar, P. and Chakravarty, S. (2011). Status of soil carbon sequestration under different land use systems in Terai Zone of West Bengal, Environment \& We: An. Int. J. Sci. Tech., 6, 95-100.

37. Kraus David, Sebastian Weller, Steffen Klatt, Ignacio Santabárbara, Edwin Haas, Reiner Wassmann, Christian Werner, Ralf Kiese and Klaus Butterbach-Bahl (2016). How well can we assess impacts of agricultural land management changes on the total greenhouse gas balance $\left(\mathrm{CO}_{2}, \mathrm{CH}_{4}\right.$ and $\left.\mathrm{N}_{2} \mathrm{O}\right)$ of tropical rice-cropping systems with a biogeochemical model? Agriculture Ecosystems and Environment, 224, 104-115.

38. Kukal, S.S., Rasool, R. and Benbi, D.K. (2009). Soil organic carbon sequestration in relation to organic and inorganic fertilization in rice-wheat and maize-wheat systems. Soil Till. Res., 102, 87-92.

39. Kundu, S., Dotaniya, M.L. and Lenka, S. (2013). Carbon sequestration in Indian agriculture. In: Lenka, S., Lenka, N.K., Kundu, S. and Rao, A.S. (eds) Climate change and natural resources management, $1^{\text {st }}$ edn. New India Publishing Agency, New Delhi, pp 269-289

40. Lal, R. (2014). Societal value of soil carbon. Journal of Soil and Water Conservation, 69(6), 186A-192A, doi:10.24 89/jswc.69.6.186A.
41. Lee, D.K., Doolittle, J.J. and Owens, V.N. 2007. Soil carbon dioxide fluxes in established switchgrass land managed for biomass production. Soil Biol. Biochem., 39, 178186.

42. Li, N, Kumar, P, Lai, LM, Abagandura, GO, Kumar, S, Nleya, T, Sieverding, HL, Stone, JJ, Gibbons, W. (2019). Response of soil greenhouse gas fluxes and soil properties to nitrogen fertilizer rates under Camelina and Carinata nonfood oilseed crops. BioEnergy Research, 12(3), 524 -535.DOI: http://dx.doi. org/10.1007/s12155-019-09987-4.

43. Li, Z, Zeng, Z, Tian, D,Wang, J, Fu, Z, Zhang, F, Zhang, R, Chen, W, Luo, Y, Niu, S. (2020). Global patterns and controlling factors of soil nitrification rate. Global Change Biology, 00, 1-11. DOI: http://dx. doi.org/10.1111/gcb.15 119.

44. Lin, S., Zhang, S., Shen, G., Shaaban, M., Ju, W., Cui,Y., Duan, C., and Fang, L. (2021). Effects of inorganic and organic fertilizers on $\mathrm{CO} 2$ and $\mathrm{CH} 4$ fluxes from tea plantation soil. J.Elem Sci Anth., 9(1), 2-13. DOI: https:// doi.org/10.1525/elementa.2021.090

45. Lindau, CW., Bollich, P.K., De Laune, R.D., Moiser, A.R. and Bronson, K.F. (1993). Methane mitigation in flooded Louisiana rice fields. Biol. Fertil. Soils, 15 (3), 174-180.

46. Linquist, B.A., Adviento-Borbe, M.A., Pittelkow, C.M., van Kessel, C. and Van Groenigen, K.J. (2012). Fertilizer management practices and greenhouse gas emissions from rice systems: A quantitative review and analysis. Field Crops Res., 135, 10-21.

47. Liu, H, Ding, Y, Zhang, Q, Liu, X, Xu, J, Li, Y, Di, H. (2018). Heterotrophic nitrification and denitrification are the main sources of nitrous oxide in two paddy soils. Plant and Soil 445(1-2), 39-53. DOI: http://dx.doi.org/10.1007/ s11104-018-3860-x.

48. Liu, J, Li, N, Zhang,W,Wei, X, Tsang, D, Sun, Y, Luo, X, Bao, Z, Zheng,W,Wang, J, Xu, G, Hou, L, Chen, Y, Feng, $Y$. (2019). Thallium contamination in farmlands and common vegetables in a pyrite mining city and potential health risks. Environmental Pollution, 248, 906-915. DOI: http:// dx.doi.org/10.1016/j.envpol. 2019.02.092.

49. Maheswara Prasad, V. and Prabhu Prasadini, P. (2014). Influence of integrated nutrient management on microbial biomass and enzymes under long-term rice-rice cropping system in Alfisols. The Andhra Agrc. J., 61(4), 841-850.

50. Majumdar, D., Kumar, S. and Jain, M.C.(1999). Methane production potential of some Indian soils. Asia Pacific. J. Environ. Sci., 6, 81- 85.

51. Manivannan, R. and Sriramachandrasekharan, M.V. (2016). Dynamics of inorganic fractions of nitrogen in an ustifluvents soil on incorporation of organic manures and mineral nitrogen in rice. International Journal of Development Research, 6(9): pp.9333-9338.

52. Matthews, R.B., Wassmann, R. and Arah, J.R.M. (2000). Using a crop-soil simulation model and GIS techniques to assess methane emissions from rice fields in Asia. I. Model development. Nutr. Cycl. Agroecosyst., 58: 11-159.

53. Mitra, S., Jain, M.C., Kumar, S., Bandyopadhyay, S. K. and Kalra, N. (1999). Effect of methane emission. Agric Ecosyst Environ, 73(3): 177-183.

54. Moharana, P.C., Sharma, B.M. Biswas, D.R., Dwivedi, B. S. and Singh, R.V. (2012). Long-term effect of nutrient management on soil fertility and soil organic pools under a 6 year-old Pearl millet - wheat cropping system in an In- 
ceptisol of subtropical India. Field crops Research, 136: 32-41.

55. Naher, U.A., Hashem, M.A., Uddin, M.K., Ahmed, M. and Saleque, M.A. (2004). Carbon mineralization and carbon dioxide evolution rate of cow dung and poultry manure along with rice straw and lime under covered condition in the tropical environment. Pak. J. Biol. Sci., 7 (2):155158.

56. Naresh, R.K., Arvind Kumar, R.K. Gupta, A.K. Shukla, S.S. Dhaliwal, R.S. Rathore, Vivek, Mukesh Kumar, S.P. Singh, Satyaveer Singh, S.S. Tomar, Hans Raj, S.P. Singh, R.C. Rathi, N. C. Mahajan and Rajendra Kumar (2018. Organic and conservation systems enhanced carbon sequestration potential and soil carbon stock dynamics: A review. Journal of Pharmacognosy and Phytochemistry, 7(2): 2362-2390.

57. Nayak, A.K., Gangwar, B.,Shukala, A.K., Mazumdar, S.P. and Kumar, A.K. (2012). Long-term effect of different integrated nutrient management on soil organic carbon and its fraction and sustainability of rice-wheat system in Indo Gangetic plains of India. Field crop Res., 127: 129-139.

58. Nungkat, P., Kusuma, Z. and Handayanto, E. (2014). Effects of organic matter application on methane emission from paddy field adopting organic farming system. $J$. Degraded and Mining Lands Managements, 2(2): 303312.

59. Nyamadzawo, G, Wuta, M, Nyamangara, J, Smith, J.L, Rees, R.M. (2014). Nitrous oxide and methane emissions from cultivated seasonal wetland (dambo) soils with inorganic, organic and integrated nutrient management. Nutrient Cycling in Agroecosystems 100(2): 161-175. DOI: http://dx.doi.org/10.1007/ s10705-014-9634-9.

60. Onwudike, S.U. (2010). Effectiveness of cow dung and mineral fertilizer on soil properties, nutrient uptake and yield of sweet potato (Ipomoea batatus) in Southeastern Nigeria. Asian J. Agric. Res., 4:148-154.

61. Oo, A.Z., Win, K.T. and Bellingrath-Kimura, S.D. (2015). Within field spatial variation in methane emissions from lowland rice in Myanmar. Springer Plus, 4:145.

62. Pascal, R.S. and Renin, W. E. (1997). Interactions between dehydrogenase activities and soil characteristics at some locations in the republic. PI.Production., 43, 415419.

63. Pathak, H., Bhatia, A. and Jain, N. (2014) Greenhouse Gas Emission from Indian Agriculture: Trends, Mitigation and Policy Needs. Indian Agricultural Research Institute, New Delhi, xvi+39 p.

64. Pathak, H., Bhatia, A., Shiv Prasad, Singh, S., Kumar, S., Jain, M. C. and Kumar, U. (200)2. Emission of nitrous oxide from soil in rice-wheat systems of Indo-Gangetic plains of India. Environ. Monitoring Assessment, 77(2), 163-178.

65. Pathak, H., Byjesh, K., Chakrabarti, B. and Aggarwal, P.K. (2011). Potential and cost of carbon sequestration in Indian agriculture: Estimates from long-term field experiments. Field Crops Res., 120,102-111.

66. Pathak, H., Jain, N., Bhatia, A., Patel, J. and Aggarwal, P.K. (2010) Carbon footprints of Indian food items Agric Ecosys Environ, 139, 66-73

67. Pothare, S., Rathod, P.K.,Ravankar, H.N., Patil, Y.G., Yewale, A.C. and Pothare, D. (2007). Effect of long- term fertilization in vertisols on soil properties and yield of sorghum wheat sequence. The Asian J. Soil Sci. 2(1): 74 $-78$.

68. Pradhan, S., Bastia, D.K. and Tripathy, S. (2015). Soil organic carbon health and yield sustainability under organically managed rice-rice sequence. J. Crop and Weed, 11(1):108-112.

69. Puttaso, A., Vityakon, P.,Saenjan, P.,Trelo-ges, V. and Cadisch, G. (2011). Relationship between organic matter accumulation in a tropical sandy soil after 13 years. Nutr. Cycl Agroecosystem, 89, 159-174.

70. Qaswar, M, Jing, H, Ahmed,W, Li, D, Liu, S, Lu, Z, Cai, A, Lisheng, L, Yongmei, X, Jusheng, G, Huimin, $Z$. (2020). Yield sustainability, soil organic carbon sequestration and nutrients balance under longterm combined application of manure and inorganic fertilizers in acidic paddy soil. Soil \& Tillage Research198, 104569. DOI: http://dx.doi.org/10. 1016/j.still.2019.104569.

71. Qiu, Q.Y, Wu, L. F, Ouyang, Z, Li, B. B, Xu, Y. Y, Wu, S. S, Gregorich, E. G. (2015). Effects of plant-derived dissolved organic matter (DOM) on soil CO2 and N2O emissions and soil carbon and nitrogen sequestrations. Applied Soil Ecology 96: 122-130. DOI:http:// dx.doi.org/10.1016/j.apsoil.2015.07.016.

72. Ravikumar, C. and Ganapathy, M. (2018). Effect of combined use of organic manures and inorganic fertilizers on the methane fluxes in rice crop (Oryza sativa), Journal of Emerging Technologies and Innovative Research, 5(11): 555-570 http://doi.one/10.1729/Journal.18866

73. Redeker, KR., Wang, N.Y., Low, J.C., McMillan, A., Tyler, S.C. and Cicerone, R.J. (2000). Emissions of methyl halides and methane from rice paddies. Science, 3: 966969.

74. Reichardt, W., Mascarina, G., Padre, B. and Doll, J. 1997. Microbial communities of continuously cropped, irrigated rice fields. Appl. Envron. Microbio.,63: 233-38.

75. Rochette, P., Angers, D.A., Chantigny, M.H., Bertrand, N. and Cote, D. (2004). Carbon dioxide and nitrous oxide emissions following fall and spring applications of pig slurry to an agricultural soil. Soil Sci. Soc. Am. J., 68: 1410-1420.

76. Salehi, A., Fallah, S. and Sourki, A.A. (2017). Organic and inorganic fertilizer effect on soil $\mathrm{CO} 2$ flux, microbial biomass, and growth of Nigella sativa L. Int. Agrophys., 31: $103-116$

77. Samahadthai, P., Vityakon, and Saenjan, P. (2010). Effects of different quality plant residues on soil carbon accumulation and aggregate formation in a tropical sandy soil in northeast Thailand as revealed by a 10 year field experiment. Land degradation and development, 21, 46473.

78. Sampanpanish, P. (2012). Effect of organic fertilizer use in rice paddy to reduce greenhouse gases. Int. Conf. Environ. Agric. Eng., 37, 79-85.

79. Sass, R.L., Fisher, F.M., Lewis, S.T.,Jund, M.F. and Turner, F.T. (1994). Methane emission from rice fields: Effect of soil properties, Global Biogeochemical Cycles, 8 (2):135-140.

80. Scherer, H.W. (2009). Sulphur in soils. Journal of Plant Nutrition and Soil Science, 172, 326. https://doi.org/10.10 02/jpln.200900037

81. Schimel, J. (2000). Global change: Rice, microbes and 
Ravikumar, C. et al. / J. Appl. \& Nat. Sci. 13(1): 385 - 395 (2021)

methane. Nature, 403: 375-377.

82. Segada, Z., Bonzi, M.,Gnankambary, Z.,Lompo, F. and Sedogo, M.P. (2014). Influence of soil fertility management on organic carbon mineralization in irrigated rice. $J$. Agrl. Crop Res., 2 (2), 32-43.

83. Sharma, K.L., Sharma, S.C., Bawa, S.S. Sher Singh, Chandrika, D.S. and Grace, J.K. 2015. Effects of Conjunctive Nutrient Management on Soil Fertility and Overall Soil Quality Index in SubmountainousInceptisol Soils under Rainfed Maize (Zea mays L.)-Wheat (Triticum aestivum) System. Commu. Soil Sci. Plant Anal., 46, 47-61.

84. Singh, R., Singh, Y.P., Yaduvanshi, N.P.S. and Sharma, D.K. (2009). Effect of irrigation scheduling and integrated nutrient management on yield of rice - wheat system and properties of a reclaimed sodic soil. Journal of the Indian Society of Soil Science, 57(3): 280-86.

85. Singh, R.B. (2000). Environmental consequences of agricultural development: a case study for the green revolution state of Haryana, India. Agr. Ecosys. Environ., 82: 97103.

86. Smith, K.A., Ball, T., Conen, F., Dobbie, K.E., Massheder, J. and Rey, A. (2003). Exchange of greenhouse gases between soil and atmosphere: interactions of soil physical factors and biological processes. Eur. J. Soil Sci., 54: 779791.

87. Suwannarit, A. (2008). Fertilizer for agriculture and the environment (2nd ed.). Kasetsart University, Bangkok.

88. Tang, C., Sparling, G.P.,McLay, C.D.A. and Raphael, C. (1999). Effect of short-term legume residue decomposition on soil acidity, Australian Soil Research, 37: 3, 561-573.

89. UshaRani, K., Sharma, K.L., Nagasri, K., Srinivas, K., Vishnu Murthy, T., Maruthi Shankar, G.R., Korwar, G.R., Sridevi Shankar, K., Madhavi, M. and Kusuma Grace, J. (2009). Response of sunflower to sources and levels of sulphur under rainfed semi-arid tropical conditions. Commun. Soil Sci. Plant Analysis, 40, 2926- 2944.

90. Valentini, R., Matteucci, G. and Jarvis, P.G. 2000. Respiration as the main determinant of carbon balance in European forests. Nature, 404, 861-865.

91. Wang, J., Wang, C., Chen, N.,Xiong, Z., Wolfe, D. and Zou, J. (2015). Response of rice production to elevated $\mathrm{CO} 2$ and its interaction with rising temperature or nitrogen supply A meta-analysis. Climate Change, DOI10.1007/ s10584-015-1374-6.

92. Wang, W., Lai, D.Y.F., Wang, C., Tong, C. and Zeng, C. (2016). Effects of inorganic amendments, rice cultivars and cultivation methods on greenhouse gas emissions and rice in a subtropical paddy field. Ecol. Eng., 95, 770-778.

93. Wassmann, R. and Aulakh, M.S. (2000). The role of rice plants in regulating mechanisms of methane missions. Biol. Fertil. Soils, 31, 20-29.

94. Wu, L, Zhang, W, Wei, W, He, Z, Kuzyakov, Y, Bol, R, Hu, R. (2019). Soil organic matter priming and carbon balance after straw addition is regulated by longterm fertilization. Soil Biology \& Biochemistry, 135, 383-391. DOI: http:/l dx.doi.org/10.1016/j.soilbio. 2019.06.003.

95. Wu, X,Wang, F, Li, T, Fu, B, Lv, Y, Liu, G. (2020). Nitrogen additions increase $\mathrm{N} 2 \mathrm{O}$ emissions but reduce soil respiration and $\mathrm{CH} 4$ uptake during freeze-thaw cycles in an alpine meadow. Geoderma, 363, 114157. DOI: http:// dx.doi.org/10.1016/j.geoderma.2019. 114157 .
96. Wu, X,Wang, F, Li, T, Fu, B, Lv, Y, Liu, G. (2020). Nitrogen additions increase $\mathrm{N} 2 \mathrm{O}$ emissions but reduce soil respiration and $\mathrm{CH} 4$ uptake during freeze-thaw cycles in an alpine meadow. Geoderma 363, 114157. DOI: http:// dx.doi.org/10.1016/j.geoderma.2019. 114157.

97. 100.Xiang, R. and Ng, C. H. (1996). Methane emission in rice field of Thailand. Journal of Environmental Sciences. 8(1): 38-47.101.

98. Yadav, R.L., Dwivedi, B.S. and Pandey, P.S. (2000). Ricewheat cropping system: Assessment of sustainability under green manuring and chemical fertilizer input. Field Crop Res., 65, 15-30.

99. 102. Yadav, S.K., Khokar, U.V. and Yadav, R.P. (2010). Integrated nutrient management for strawberry cultivation. Indian journal of horticulture, 67, 445-449.

100.Yan, D., Wang, D. and Yang, L. (2007). Long-term effect of chemical fertilizer, straw, and manure on labile organic matter fractions in a paddy soil. Biol. Fertil. Soils., 44, 93101.

101.Yang, S.S. and Chang, E.H. 1997. Effect of fertilizer application on methane emission/ production in the paddy soils of Taiwan. Biol. Fert. Soils,25, 245-51.

102. Yu, QG, Hu, X, Ma, JW, Ye, J, Sun, WC,Wang, Q, Lin, H. (2020). Effects of long-term organic material applications on soil carbon and nitrogen fractions in paddy fields. Soil \& Tillage Research, 196, 7. DOI: http://dx.doi.org/10.1016/ j.still.2019.104483.

103.Yuan, Q., Pump, J. and Conrad, R. (2014). Straw application in paddy soil enhances methane production also from other carbon sources. Bio geosciences, 11, 237-246.

104.Yuan, Y., Li, H. and Huang, Q. (2004). Effects of different fertilization on soil organic carbon distribution and storage in micro- aggregates of red paddy topsoil. Acta Ecologica, Sinica, 24, 2961-2966.

105.Zhang, K., Wang, Z., Xu, Q., Liu, B., Duan, M. and Wang, I. (2020). Effect of controlled-release ureafertilizers for oilseed rape (Brassicanapus L.) on soil carbon storage and $\mathrm{CO}_{2}$ emission. Environmental Science and Pollution Research,27, 31983-31994.

106.Zhang, L.H., Shao, H.B., Wang, B.C., Zhang, L.W., Qin, X.C. (2019). Effects of nitrogen and phosphorus on the production of carbon dioxide and nitrous oxide in saltaffected soils under different vegetation communities.Atmospheric Environment,204: 78-88. DOI: http:// dx.doi.org/10.1016/j.atmosenv.2019. 02.024.

107.Zhou, G, Cao, W, Bai, J, Xu, C, Zeng, N, Gao, S, Rees, RM. (2019). Non-additive responses of soil $C$ and $N$ to rice straw and hairy vetch (Vicia villosa Roth L.) mixtures in a paddy soil. Plant and Soil,436(1-2): 229-244. DOI: http://dx.doi.org/10.1007/s11104-018-03926-6.

108.Zhou, GP, Gao, SJ, Xu, CX, Dou, FG, Shimizu, KY, Cao,W.2020. Rational utilization of leguminous green manure to mitigate methane emissions by influencing methanogenic and methanotrophic communities.Geoderma,361: 12. DOI: http://dx.doi.org/10.1016/ j.geoderma.2019.114071.

109.Zhou, ZH, Wang, CK, Jin, Y. (2017). Stoichiometric responses of soil microflora to nutrient additions for two temperate forest soils. Biology and Fertility of Soils, 53(4): 397- 406. DOI: http://dx.doi.org/10. 1007/s00374-0171188-y. 